\title{
The Effect of Conventional Fertilisation on the Growth and Yield of Palomino Vines on Fertile Soil
}

\author{
D. SAAYMAN and W. J. CONRADIE \\ Oenological and Viticultural Research Institute, Private Bag X5026, Stellenbosch, 7600 \\ Grateful acknowledgement is due to Mr. G. J. J. Albertse and the Misses A. E. Theron and A. Verster for their able technical assistance.
}

\begin{abstract}
The effect of two levels of conventional fertiliser applications on the performance of Palomino grapes on the fertile soil of the Olifants River region was studied. Soil, leaf and must analyses, and shoot and crop mass were used as indicators of fertiliser response. A tendency towards improved shoot mass but no significant effect on crop mass due to fertilisation was found. Leaf and must analyses did not reflect treatments, probably because of a natural luxurious $P$ and $K$ supply in the soil concerned, which was calculated to be sufficient for at least 20 years. However, the soil seemed to be on the borderline in its $\mathrm{N}$ supplying capabilities for a production level of $\mathbf{4 0} \mathrm{t} / \mathrm{ha}$.

The importance of phylloxera as a growth and production limiting factor in comparison with fertilisation was demonstrated. No $\mathrm{P}$ or $\mathrm{K}$ fertilisation is recommended for these soils, and a yearly application of $90 \mathrm{~kg} \mathrm{~N} / \mathrm{ha}$ is suggested as a guideline for $\mathrm{N}$ fertilisation.
\end{abstract}

During the last two decades, vineyard production outside the traditional vineyard areas of the Western Cape and Breede River valley became increasingly important, e.g. in the irrigation area of the Olifants River, situated approximately $250 \mathrm{~km}$ north of Cape Town, which already produces 12,5 per cent of the national grape crop. The soils of this area are mainly dark coloured alluvial and red, calcareous so-called "dorbank" (duripan) soils, exceptionally rich in plant nutrients in comparison with the soils of the traditional Western Cape wine regions. The climate is hot and dry but sufficient irrigation water of a good quality is available, and high yields of more than 50 t/ha are easily obtained, the largest portion of which is used for distillation. Under these circumstances it is unlikely that fertilisation practices as applied in the Western Cape would be directly applicable to this fertile area. It is estimated that in the Olifants River area about R0,7 million is spent on fertiliser annually, in spite of the fact that there is no scientific evidence for intensive fertilisation. In order to test the necessity of fertilisation, a fertiliser experiment was initiated during 1973, and results obtained over a nine-year period are presented in this paper.

\section{MATERIALS AND METHODS}

The experiment was conducted on the O V R I experimental farm at Lutzville in an existing Palomino vineyard in full production and trained on a Perold trellising system (Zeeman, 1981). Vines grafted on 99R, alternated with ungrafted vines in the row. The soil, of alluvial origin, was situated at the confluence of the red duripan soil and the dark coloured, alluvial, so-called silty soil. The soil concerned was, therefore, a mixture of the two soil types commonly occurring in the area.

Only three fertiliser treatments were applied, viz. A $300 \mathrm{~kg} 3.1 .5$ (26)/ha (c. $26 \mathrm{~kg} \mathrm{~N}$; 9 kg P; $43 \mathrm{~kg} \mathrm{~K}$ ) applied during bud burst (end September), plus a top dressing of $120 \mathrm{~kg} \mathrm{LAN} *$ (30)/ha (36 kg N) during bloom (November), followed by another $300 \mathrm{~kg} 3.1 .5$ (26) immediately after harvest (March). This treatment amounted to $c .88 \mathrm{~kg} \mathrm{~N}, 18 \mathrm{~kg} \mathrm{P}$ and $86 \mathrm{~kg} \mathrm{~K}$ per hectare, theoretically sufficient to compensate for N P K removed by a crop of 40 tons (Saayman, 1974; Conradie, 1981).

B $150 \mathrm{~kg} 3.1 .5$ (26)/ha during bud burst, $60 \mathrm{~kg}$ LAN/ha in November and again $150 \mathrm{~kg} \mathrm{3.1.5} \mathrm{(26)/ha}$ immediately after harvest, i.e. half the quantities of treatment A.

C Control, no fertiliser application.

The experimental design was a randomised block layout, consisting of six replicates of three treatments each. Each plot was flanked by two buffer rows and four vines on all sides, and contained 18 experimental vines of which nine were grafted on $99 \mathrm{R}$ and the rest were ungrafted. Prior to the commencement of the trial, the vineyard had received no fertiliser, and the first shoot mass determinations were executed at this stage. The first treatments were applied during the spring of 1972 and continued until 1980. The first yield determinations were carried out during the end of the 1972/73 season.

Soil samples were collected during 1972 before commencing differential fertilisation, and again at the end of the $1975 / 76$ season. These samples were analysed for $\mathrm{pH}$, electrical resistance and macro-nutrient content, using standard O V R I methods. Unfortunately, the vineyard was flooded at the end of 1976 when the Olifants River flooded its banks, and a thin alluvial deposit was left on the soil surface, rendering further attempts at tracing changes in soil fertility due to fertilisation not worth while.

Shoot and crop mass were measured each year, and the data from grafted and ungrafted vines were kept separate, except in the case of the 1979 and 1980 yield data. Total soluble solids (TTS) and total titratable acidity (TTA) were measured in must samples. During 1978 and 1980, must samples were also analysed for their macro-element content, using standard O V R I methods. Leaf samples were collected between véraison and harvest, taking undamaged leaves opposite bunches and separating them into leaf blades and petioles for separate analyses for macro-element content, using standard O V R I methods.

The vineyard, clean cultivated by means of a light cultivator after each irrigation, was pruned according to normal practice, i.e. twenty two-bud spurs per vine. 
The vineyard was flood irrigated at approximately fortnightly intervals at $75 \mathrm{~mm} /$ irrigation. Irrigation was discontinued from mid-January to enhance ripening. During 1976 the soil and vine roots were examined for the presence of phylloxera.

${ }^{*}$ LAN $=$ Limestone ammonium nitrate.

\section{RESULTS AND DISCUSSION}

Soil analyses: The soil analyses data in Table 1 indicate decreases in the mean phosphorus $(\mathrm{P})$ and magnesium $(\mathrm{Mg})$ content of both top and subsoil for all three treatments over a period of four years. In the case of exchangeable potassium (K), an increase of $c .5$ per cent in the topsoil was calculated for soils which received fertiliser, whereas the subsoils of all three treatments showed a $c .16$ per cent increase. Little changes in the exchangeable Ca content of both top and subsoil occurred. Although the topsoil of fertilised plots lost significantly less $\mathrm{P}$ and $\mathrm{K}$ reserves after four years than that of unfertilised plots, there was no relation between topsoil $\mathrm{P}$ and $\mathrm{K}$ reserves and fertiliser increment, and also no explanation for the apparent increase in $\mathrm{K}$ content of subsoils in general.

A tendency towards a decrease in the electrical resistance of the topsoil for all three treatments, but notably that of the control (C) plots, together with a corresponding significant increase in exchangeable sodium $(\mathrm{Na})$, indicate a slow salinisation of the soil. The reason for this is still unknown.

Shoot mass: Using the initial shoot mass of the vines before the commencement of the trial as reference point, relative changes in shoot mass of grafted and ungrafted vines, as affected by fertilisation, were calculated and are shown in Fig. 1. Over the entire experimental period, grafted vines had a mean shoot mass of 1,83 ; 1,82 and $1,57 \mathrm{~kg}$ per vine for treatments $\mathrm{A}, \mathrm{B}$ and $\mathrm{C}$, respectively, but no significant differences between treatments existed in any particular year, in spite of an obvious tendency for unfertilised vines (treatment C) to have a lower shoot mass than vines receiving fertiliser (treatments A and B). However, the cumulative shoot mass over the period concerned of the vines from treatment $C$ was significantly lower at a 10 per cent significance level than those of vines from treatments $A$ and $B$ (data not shown). Shoot mass of vines from treatments A and B did not differ significantly.

TABLE 1

Chemical analyses of soil samples from a fertiliser trial in the Olifants River area as affected by differential fertilisation after four years

\begin{tabular}{|c|c|c|c|c|c|c|c|}
\hline \multirow{3}{*}{$\begin{array}{l}\text { Measured soil } \\
\text { property }\end{array}$} & \multirow{3}{*}{$\begin{array}{l}\text { Fertiliser } \\
\text { treatment }\end{array}$} & \multicolumn{6}{|c|}{ Soil depth } \\
\hline & & \multicolumn{3}{|c|}{$0-30 \mathrm{~cm}$} & \multicolumn{3}{|c|}{$30-60 \mathrm{~cm}$} \\
\hline & & $\begin{array}{l}\text { Final } \\
\text { analysis }\end{array}$ & $\begin{array}{c}\text { Change }^{\mathrm{a}} \\
\text { over } 4 \\
\text { years } \\
(\%)\end{array}$ & $\begin{array}{c}\text { Significance }^{b} \\
\text { between } \\
\text { treatments }\end{array}$ & $\begin{array}{c}\text { Final } \\
\text { analysis }\end{array}$ & $\begin{array}{l}\text { Change } \\
\text { over } 4 \\
\text { years }\end{array}$ & $\begin{array}{l}\text { Signifance } \\
\text { between } \\
\text { treatments }\end{array}$ \\
\hline $\mathrm{pH}(\mathrm{KC} 1)$ & $\begin{array}{l}\text { A } \\
\text { B } \\
\text { C }\end{array}$ & $\begin{array}{l}7,38 \\
7,37 \\
7,27\end{array}$ & $\begin{array}{ll}- & 1,1 \\
- & 1,1 \\
- & 2,7\end{array}$ & NS & $\begin{array}{l}7,55 \\
7,58 \\
7,54\end{array}$ & $\begin{array}{l}-0,3 \\
-\quad 1,2 \\
-\quad 0,4\end{array}$ & NS \\
\hline $\begin{array}{l}\text { Electrical } \\
\text { resistance } \\
(\text { ohm })\end{array}$ & $\begin{array}{l}\text { A } \\
\text { B } \\
\text { C }\end{array}$ & $\begin{array}{l}472 \\
444 \\
336\end{array}$ & $\begin{array}{l}-16 \\
-25 \\
-50\end{array}$ & NS & $\begin{array}{l}508 \\
552 \\
681\end{array}$ & $\begin{array}{l}-16 \\
-7 \\
-7\end{array}$ & NS \\
\hline$P(p p m)$ & $\begin{array}{l}\mathrm{A} \\
\mathrm{B} \\
\mathrm{C}\end{array}$ & $\begin{array}{l}340 \\
318 \\
305\end{array}$ & $\begin{array}{l}-12 \\
-12 \\
-20\end{array}$ & $\mathrm{D}=28$ & $\begin{array}{l}161 \\
163 \\
146\end{array}$ & $\begin{array}{l}-14 \\
-15 \\
-18\end{array}$ & NS \\
\hline $\mathrm{K}(\mathrm{me} \%)$ & $\begin{array}{l}\mathrm{A} \\
\mathrm{B} \\
\mathrm{C}\end{array}$ & $\begin{array}{l}1,07 \\
1,07 \\
0,93\end{array}$ & $\begin{array}{l}+5 \\
+\quad 6 \\
-\quad 5\end{array}$ & $\mathrm{D}=0,10$ & $\begin{array}{l}0,53 \\
0,50 \\
0,47\end{array}$ & $\begin{array}{l}+18 \\
+16 \\
+15\end{array}$ & NS \\
\hline $\mathrm{Na}(\mathrm{me} \%)$ & $\begin{array}{l}\text { A } \\
\text { B } \\
\text { C }\end{array}$ & $\begin{array}{l}0,21 \\
0,25 \\
0,29\end{array}$ & $\begin{array}{l}+23 \\
+32 \\
+123\end{array}$ & $\mathrm{D}=0,06$ & $\begin{array}{l}0,28 \\
0,29 \\
0,27\end{array}$ & $\begin{array}{l}-10 \\
+11 \\
+12\end{array}$ & NS \\
\hline $\mathrm{Ca}(\mathrm{me} \%)$ & $\begin{array}{l}\mathrm{A} \\
\mathrm{B} \\
\mathrm{C}\end{array}$ & $\begin{array}{l}16,1 \\
15,5 \\
15,6\end{array}$ & $\begin{array}{l}-\quad 2,2 \\
-\quad 4,2 \\
-\quad 1,4\end{array}$ & NS & $\begin{array}{r}11,7 \\
10,6 \\
9,4\end{array}$ & $\begin{array}{l}+7 \\
-5 \\
-6\end{array}$ & NS \\
\hline $\mathrm{Mg}(\mathrm{me} \%)$ & $\begin{array}{l}\mathrm{A} \\
\mathrm{B} \\
\mathrm{C}\end{array}$ & $\begin{array}{l}3,02 \\
3,01 \\
2,90\end{array}$ & $\begin{array}{l}-14 \\
-16 \\
-13\end{array}$ & NS & $\begin{array}{l}2,16 \\
3,03 \\
1,81\end{array}$ & $\begin{array}{l}-19 \\
-20 \\
-22\end{array}$ & NS \\
\hline
\end{tabular}

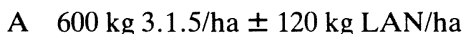

B $300 \mathrm{~kg} 3.1 .5 / \mathrm{ha} \pm 60 \mathrm{~kg} \mathrm{LAN} / \mathrm{ha}$

C Control, no fertiliser

a Analyses data of samples taken prior to commencement of trial were used as co-variant to calculate differences between treatments. Significance between final analyses of treatments therefore imply significance in percentage change over 4 years, i.e. a treatment effect on soil analyses.

b NS $=$ not significant D $=D$-value at $P \leqslant 0,05$

S. Afr. J. Enol. Vitic., Vol. 3. No. 1.1982 


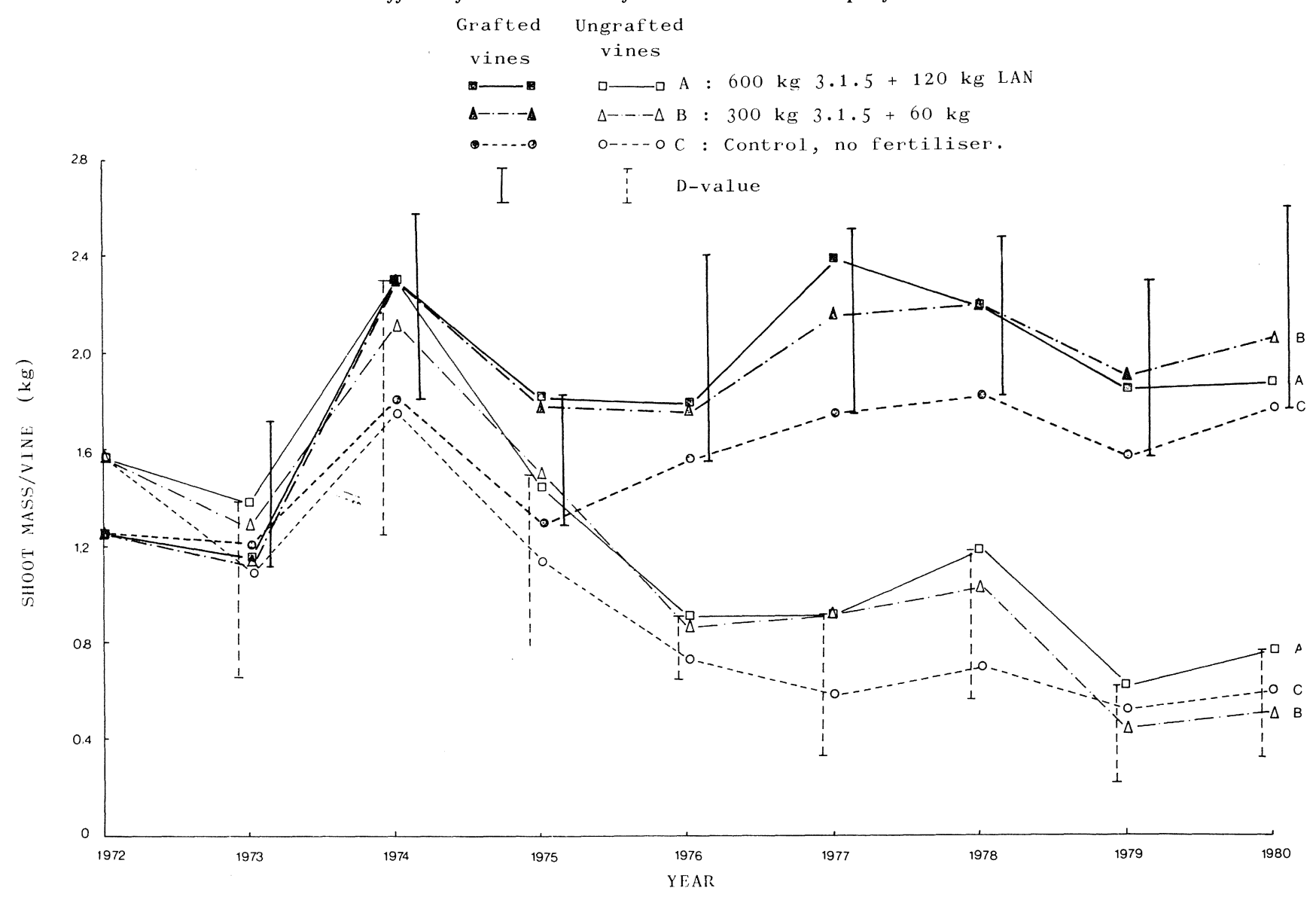

- FIg. 1 Relative changes in shoot mass of grafted and ungrafted Palomino as affected by different fertilisation, Olifants River area.

The shoot mass of ungrafted vines showed a similar pattern to that of grafted vines but declined steadily (Fig. 1), whereas grafted vines maintained a relatively steady shoot mass for the duration of the experiment. Over the nine-year experimental period the mean shoot masses of ungrafted vines were 1,$23 ; 1,13$ and $0,96 \mathrm{~kg}$ per vine for treatments $\mathrm{A}, \mathrm{B}$ and $\mathrm{C}$ respectively. Although unfertilised vines tended to have a lower shoot mass than fertilised vines, this difference was not statistically significant, not even when the cumulative shoot mass was used as criterion. Investigation of roots during 1976 showed phylloxera to be present on the roots of the ungrafted vines, and it was accepted, therefore, that phylloxera was the main cause for the decline in vigour of the ungrafted vines since 1974. The fact that ungrafted vines did not show a better response to fertilisation than grafted vines, indicates that it is not possible to revive phylloxera infested vines by means of fertilisa- tion.

Crop mass: Yields were treated in the same way as shoot mass data, and are presented in Fig. 2 (separate data for grafted and ungrafted vines were not available for 1979 and 1980). In the case of grafted vines, the mean yield over the seven-year period was 40,$6 ; 42,3$ and 40,0 tons per hectare for treatments $\mathrm{A}, \mathrm{B}$ and $\mathrm{C}$ respectively, and no significant differences occurred between treatments. In the case of ungrafted vines, no significant difference between treatments could be demonstrated, and a similar decline as for shoot mass was recorded for yield, the latter having mean values of approximately 50 per cent of that of grafted vines, i.e. 22,$4 ; 22,2$ and 19,9 tons per hectare for treatments A, B and $C$, respectively, for the seven-year period. In the final year, however, the mean yield of ungrafted vines was only $c .27$ per cent of that of grafted vines, demonstrating the magnitude of the effect of phylloxera. 


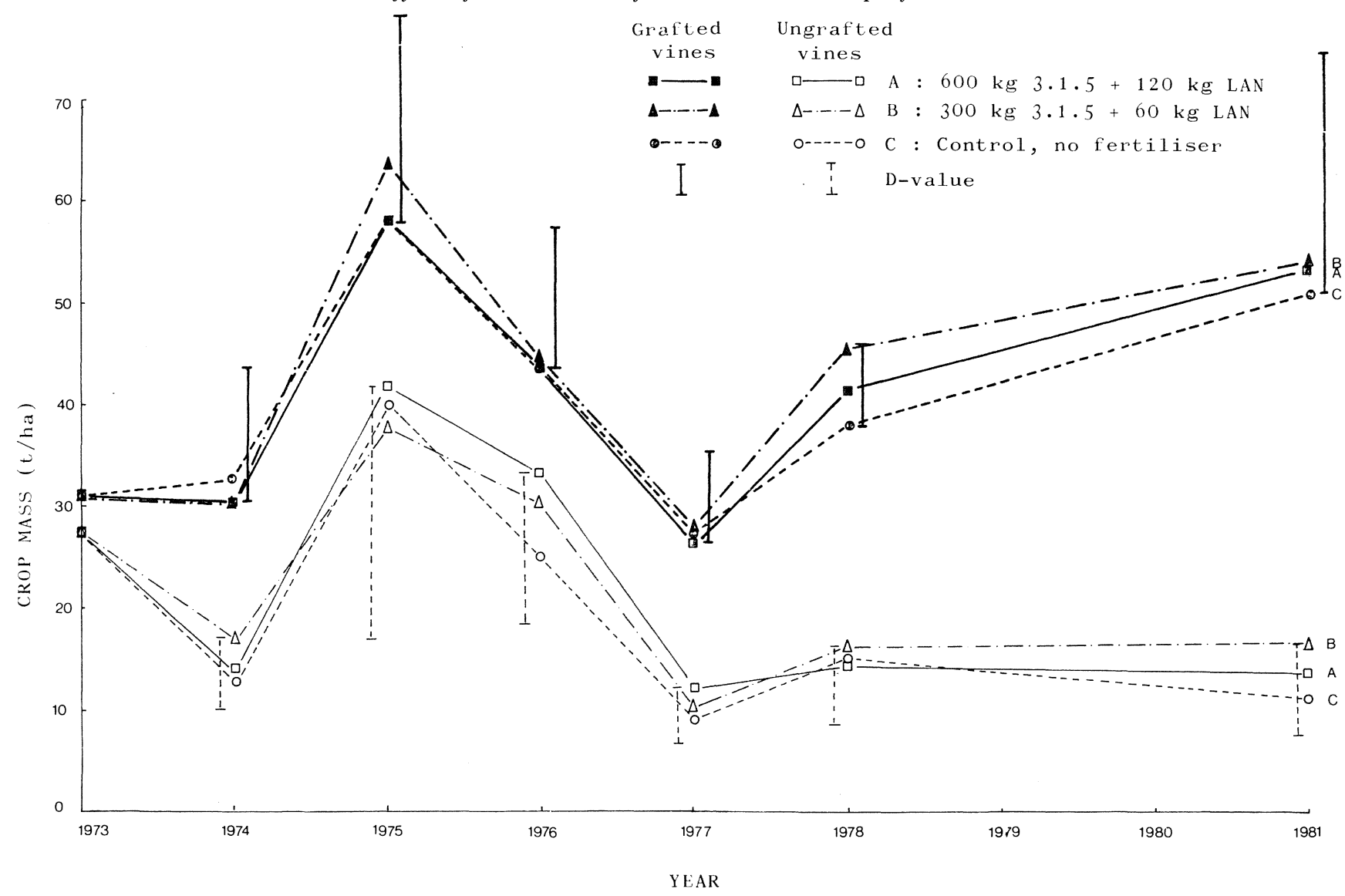

FIg. 2 Relative changes in crop mass of grafted and ungrafted Palomino as affected by differential fertilisation, Olifants River area.

Leaf analysis: The relative changes in macro-nutrient content of leaf blades and petioles for the period 1974 to 1979 , are shown in Fig. 3 and 4, respectively. Although the leaves of grafted and ungrafted vines were analysed separately, the results were eventually pooled because there were no differences between the analytical data of grafted and ungrafted vines (data not shown). Leaves were also pooled over replicates because of a shortage of analytical facilities, and no statistical analyses were therefore possible.

According to Fig. 3 and 4 there was little similarity in the nitrogen $(\mathrm{N})$ content of leaf blades (Fig. $3(\mathrm{a})$ ) and petioles (Fig. 4 (a)). The mean $\mathrm{N}$-content of leaf blades (c. 2,2 per cent) seems to be more than adequate when compared with the maximum norm of 2,4 per cent as proposed for table grapes (Beyers, 1962). The mean Ncontent of petioles was 0,64 per cent in comparison with the 0,9 per cent determined for Chenin blanc growing under optimal nutritional conditions (Conradie, 1981). Field observations showed leaves from unfertilised vines to be notably yellower in colour during harvest than those of fertilised vines, pointing to a $\mathrm{N}$ deficiency at this stage.

Because of the inconsistent and unexpected position of the $\mathrm{A}, \mathrm{B}$ and $\mathrm{C}$ graphs as far as $\mathrm{P}$ and $\mathrm{K}$ content of leaf blades and petioles are concerned (Fig. 3(a) and $4(\mathrm{a})$ ), there is little reason to suspect any effect of fertilisation on the $\mathrm{P}$ and $\mathrm{K}$ content of these organs.
The mean $\mathrm{P}$ content of blades and petioles was 0,21 per cent and 0,67 per cent, respectively, indicating a satisfactory $P$ nutrition as judged by the $0,12-0,40$ norm for table grape leaf blades (Beyers, 1962) and the 0,67 per cent found in Chenin blanc petioles (Conradie, 1981) - the latter being considered as a luxurious level. The mean $\mathrm{K}$ concentrations in blades and petioles were 0,63 per cent and 1,98 per cent, respectively, pointing to a possible $\mathrm{K}$ deficiency in the case of leaf blades as judged by table grape leaf blade norms of $0,8-1,6$ per cent (Beyers, 1962), but indicating adequate $\mathrm{K}$ nutrition in the case of petioles according to the 1,6 per cent found in sand culture for Chenin blanc (Conradie, 1981). At no stage were visual $\mathrm{K}$ deficiency symptoms encountered, and no $\mathrm{K}$ deficiency is expected in view of the fact that the exchange capacity of the soil concerned was approximately 10 per cent saturated with K. A potassium saturation percentage of 4 per cent is generally considered as adequate (Aurier, 1977). In practice a K concentration in wine grape leaf blades of more than 0,8 per cent is seldom encountered, leading to the conclusion that the $\mathrm{K}$ leaf blade norm for table grapes (late maturing Barlinka in this case), is probably too high for the earlier ripening wine grapes. The $\mathrm{K}$ concentration in Chenin blanc leaf blades of $c$. 0,70 per cent between véraison and harvest as determined under optimal nutritional conditions (Conradie, 1981), supports this view. Concerning the $\mathrm{Ca}, \mathrm{Mg}$ and $\mathrm{Na}$ content of leaf 
TABLE 2

Effect of fertilisation on the macro nutrient content of Palomino must from the Olifants River area during two seasons

\begin{tabular}{|c|c|c|c|c|c|c|c|c|c|c|}
\hline \multirow{3}{*}{ Fertiliser Treatment } & \multicolumn{10}{|c|}{ Element in must $(\mathrm{mg} / \ell)$} \\
\hline & \multicolumn{2}{|c|}{$\mathrm{N}$} & \multicolumn{2}{|c|}{$\mathrm{P}$} & \multicolumn{2}{|c|}{$\mathrm{K}$} & \multicolumn{2}{|c|}{$\mathrm{Ca}$} & \multicolumn{2}{|c|}{$\mathrm{Mg}$} \\
\hline & 1978 & 1980 & 1978 & 1980 & 1978 & 1980 & 1978 & 1980 & 1978 & 1980 \\
\hline$\overline{\mathrm{A}}$ & 578 & 531 & 134 & 112 & 1191 & 487 & 33 & 38 & 60 & 58 \\
\hline B & 498 & 549 & 122 & 123 & 1007 & 613 & 56 & 44 & 59 & 63 \\
\hline $\mathrm{C}$ & 489 & 589 & 142 & 131 & 1126 & 727 & 37 & 44 & 63 & 64 \\
\hline Significance $^{\mathrm{a}}$ (D value) & $*(72)$ & NS & NS & $*(17)$ & NS & NS & NS & NS & NS & NS \\
\hline
\end{tabular}

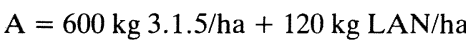

$\mathrm{B}=300 \mathrm{~kg} 3.1 .5 / \mathrm{ha}+60 \mathrm{~kg} \mathrm{LAN} / \mathrm{ha}$

$\mathrm{C}=$ Control, no fertiliser

a ${ }^{*}$ Significant $(P \leqslant 0,05)$

$\mathrm{NS}=$ Not significant

blades and petioles, only the $\mathrm{Ca}$ concentration in the petioles shows a consistent pattern (Fig. 4 (b)) that was not related to the differences found between $\mathrm{A}, \mathrm{B}$ and C plots (Table 1).

Must analysis: The concentrations of macro-nutrients in the must during 1978 and 1980 are shown in Table 2, the data for grafted and ungrafted vines being pooled as in the case of leaf analyses. Only during 1978 did fertilisation significantly increase the $\mathrm{N}$ content of the must but, on the other hand, significantly lowered the P content of the must during 1980 . This result cannot be ascribed to a dilution effect, because no significant difference in crop mass was recorded. There is no consistent logical pattern in the nutrient content of the must. This gives the impression that, as in the case of the leaves, must is no reliable indicator of the nutritional status of the vine. The insensitivity of must analyses to fertiliser treatment may be due to the high inherent fertility of the soil concerned, and different results may be obtained under less favourable soil conditions.

Although TSS and TTA determinations on the must were carried out each year, no significant difference between treatments was obtained, and only the mean values for the nine-year period are shown in Table 3. Characteristic of the Palomino cultivar, the TTA was less than $5 \mathrm{~g} / \ell$ at a TSS content of $19^{\circ} \mathrm{B}$.

Nutrient removal: Calculations made from the must analyses data in Table 2 , and the known ratio of $\mathrm{N}, \mathrm{P}$ and $\mathrm{K}$ present in must, skins and stems of Palomino grapes (Saayman, 1973), showed that the mean crop of c. $40 \mathrm{t} /$ ha produced by the grafted vines, would remove c. $42 \mathrm{~kg} \mathrm{~N}, 8 \mathrm{~kg} \mathrm{P}$ and $48 \mathrm{~kg} \mathrm{~K}$, which is well below the $88 \mathrm{~kg} \mathrm{~N}, 18 \mathrm{~kg} \mathrm{P}$ and $86 \mathrm{~kg} \mathrm{~K}$ supplied by the A treatment. Even in the case of unfertilised plots it can be calculated from Table 1 , assuming a conservative minimum norm of $40 \mathrm{ppm} \mathrm{P}$ and $150 \mathrm{ppm} \mathrm{K}$ in the soil, that the vines had 1,4 ton $\mathrm{P} / \mathrm{ha}$ and 1,0 ton $\mathrm{K} / \mathrm{ha}$ readily available in the surface $30 \mathrm{~cm}$ soil layer. These amounts of $\mathrm{P}$ and $\mathrm{K}$ should be sufficient to cover crop removal for at least 20 years if the available pools are not replenished.

By assuming a yearly mineralisation rate of humus of 1 per cent, a carbon content of humus of 60 per cent, a $\mathrm{C} / \mathrm{N}$ ratio of 10 (Champagnol, 1980) and a conservative
TABLE 3

Mean total soluble solids and total titratable acidity concentrations in Palomino must as affected by fertiliser applications in the Olifants River area

\begin{tabular}{ccc}
\hline $\begin{array}{c}\text { Fertiliser } \\
\text { Treatment }\end{array}$ & $\begin{array}{c}\text { Total Soluble } \\
\text { Solids }\left({ }^{\circ} \mathrm{B}\right)\end{array}$ & $\begin{array}{c}\text { Total Titratable } \\
\text { Acidity }(\mathrm{g} / \ell)^{\mathrm{a}}\end{array}$ \\
\hline A & 18,3 & 4,98 \\
B & 18,5 & 4,98 \\
C & 18,3 & 4,94 \\
\hline
\end{tabular}

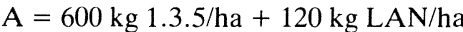

$\mathrm{B}=300 \mathrm{~kg} 3.1 .5 / \mathrm{ha}+60 \mathrm{~kg} \mathrm{LAN} / \mathrm{ha}$

$\mathrm{C}=$ Control, no fertiliser

${ }^{\text {a }}$ Expressed as tartaric acid

soil organic matter content of 1,5 per cent, it can also be calculated that the vines should have available each year $c$. $40 \mathrm{~kg} \mathrm{~N} / \mathrm{ha}$ in the top $30 \mathrm{~cm}$ soil layer. It is possible, therefore, especially for the dark coloured alluvial soils, to be self-sufficient regarding $\mathrm{N}$ supply to the vines. The soil used in this study was a mixture of dark alluvial and red sandy soil, and judged by shoot mass data, visual observations and the $\mathrm{N}$ mineralisation calculations, its ability to supply vines at a production level of 40 tons/ha with adequate $\mathrm{N}$ for vegetative growth seems to be a border-line case.

\section{CONCLUSIONS}

No evidence of a response to $\mathrm{P}$ and $\mathrm{K}$ added as 3.1.5 (26) fertiliser mixture could be found on the fertile soil concerned. This is in accordance with what could be expected of a soil containing c. $375 \mathrm{ppm} \mathrm{P}$ and $390 \mathrm{ppm} \mathrm{K}$ in the topsoil, where a $\mathrm{P}$ and $\mathrm{K}$ content of $40 \mathrm{ppm}$ and $150 \mathrm{ppm}$, respectively, is considered adequate for this particular soil. Leaf and must analyses seem to confirm this by not giving any convincing indication of a response to fertilisation. There is also little convincing evidence of serious changes in $\mathrm{P}$ and $\mathrm{K}$ reserves in the soil due to fertilisation or crop removal over a 4-year period.

Concerning $\mathrm{N}$, visual symptoms of deficiency were observed in the vineyard, and the tendencies measured with respect to shoot growth, indicate a weak response to the $\mathrm{N}$ present in the fertilisers applied. However, although certain indications of an increase in $\mathrm{N}$ content 


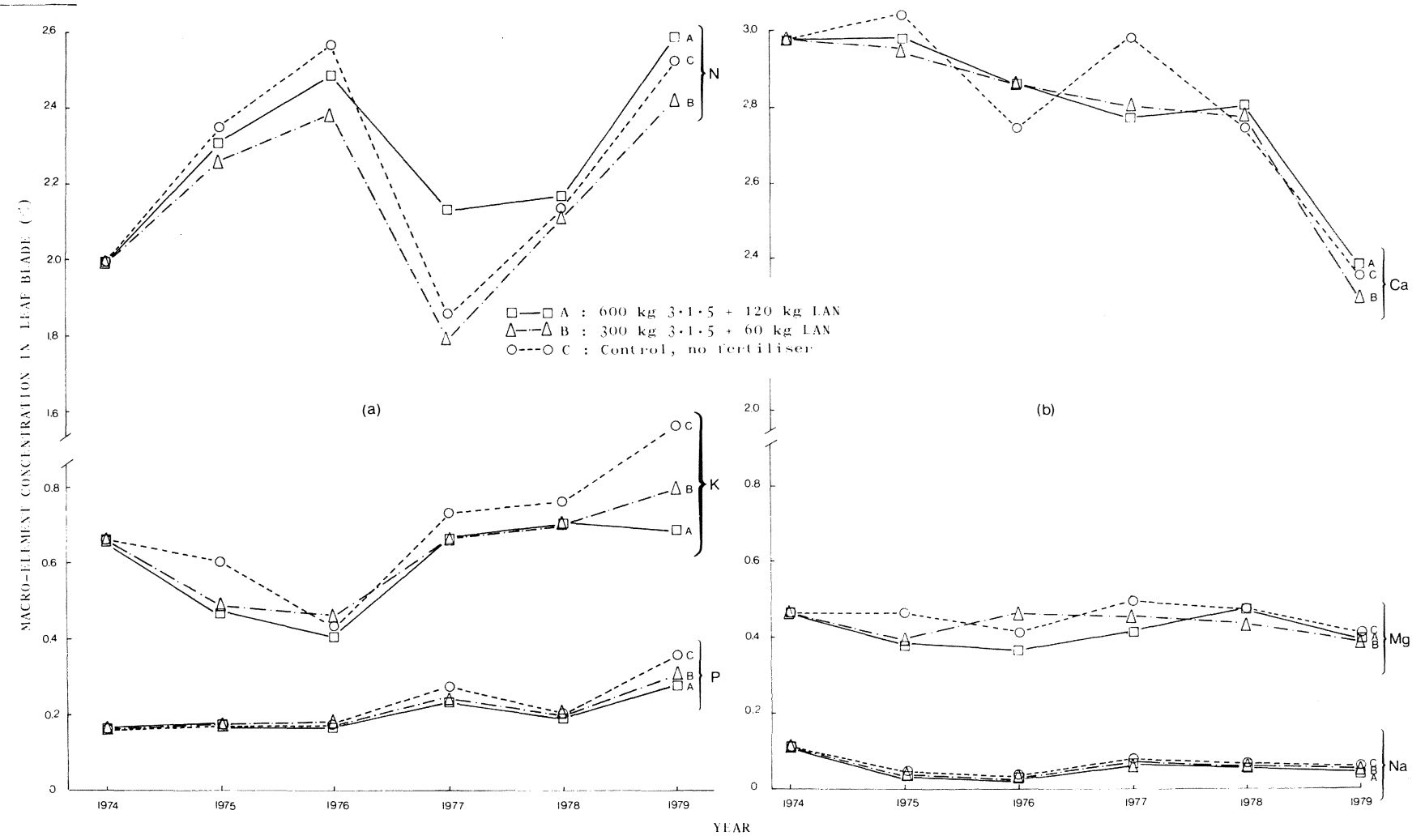

Fig. 3 Relative changes in N,P,K (a) and $\mathrm{Ca}, \mathrm{Mg}, \mathrm{Na}$ (b) concentrations in Palomino leaf blades as affected by fertilising,

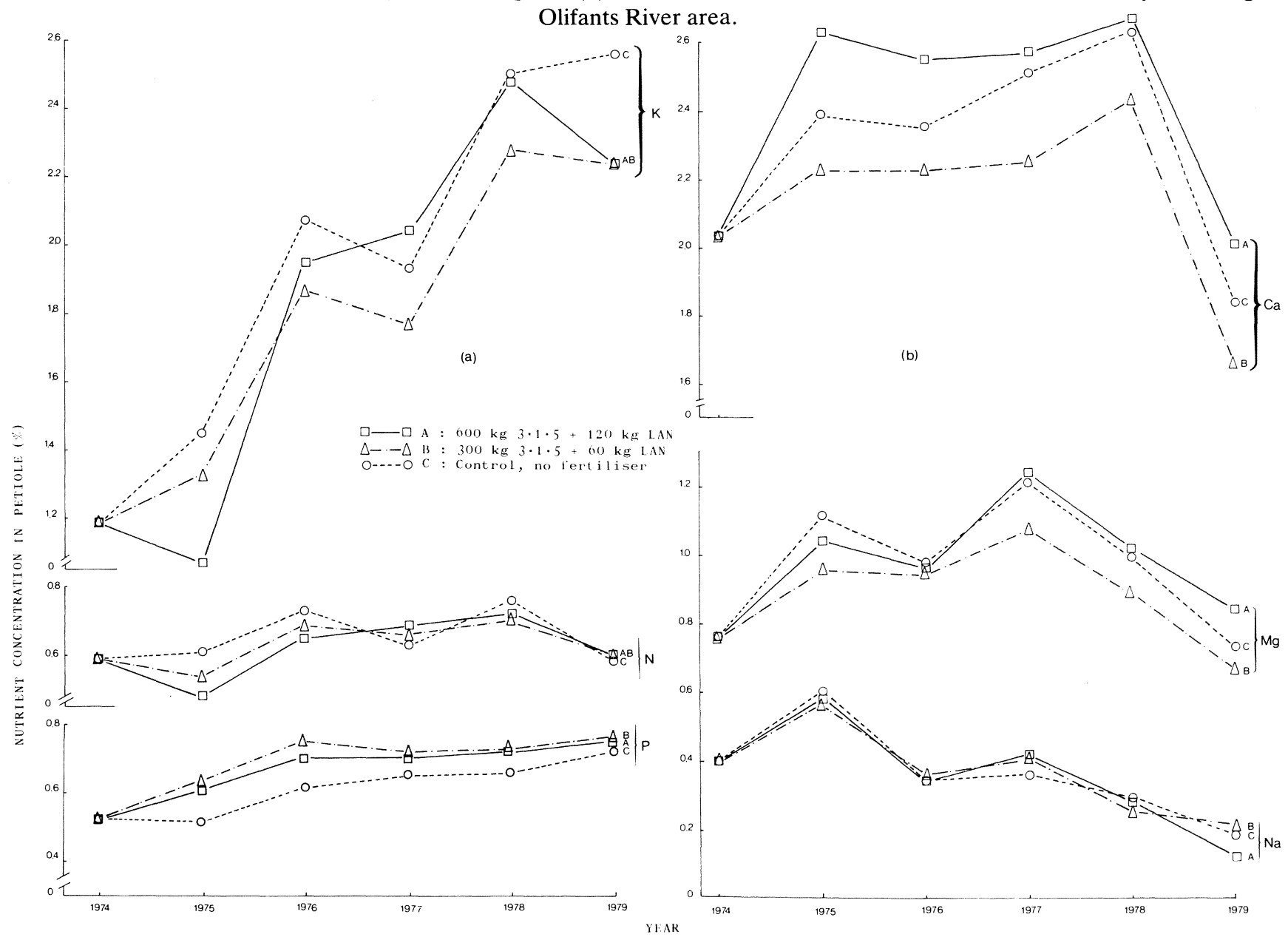

Fig. 4 Relative changes in $\mathrm{N}, \mathrm{P}, \mathrm{K}$ (a) and $\mathrm{Ca}, \mathrm{Mg}, \mathrm{Na}$ (b) concentrations in Palomino petioles as affected by fertilising, Olifants River area. 
of leaf blades and must occurred, foliar and must analyses were generally very disappointing in predicting $\mathrm{N}$ need. The fact that fertiliser treatments were not convincingly reflected by leaf and must analyses, is most probably due to the more than adequate quantities of macro-nutrients naturally present in the soil, with the possible exception of nitrogen. Calculations of nutrient removal by the crop and the ability of the soil to supply these nutrients, confirm this conclusion.

For the soils of the Lutzville area with chemical properties similar to the soil used in this study, $\mathrm{P}$ and $\mathrm{K}$ fertilisation cannot be recommended as a standard practice. Even the application of nitrogen on dark coloured alluvial soils is of doubtful value but may be necessary on red "karoo" soils having less natural organic material. An amount of $90 \mathrm{~kg} \mathrm{~N} / \mathrm{ha} / \mathrm{a}$ may be used as a guideline but must be adjusted according to the balance between vigour, yield and must quality.

In general, these results stress the importance of ensuring the elimination of seriously limiting factors like phylloxera before placing emphasis on obviously less limiting factors such as fertilisation on these fertile soils.

\section{LITERATURE CITED}

AURIER, Y., 1977. Liste des principaux essais et tests relatifs a l'alimentation de la vigne realisés par le S.U.A.D. du Gard au cours des derniers années. Colloque sur le potassium dans ses rapports avec la vigne et le vin, Montpellier, 4 mars, 1977.

BEYERS, E., 1962. Diagnostic leaf analyses for deciduous fruit. S. Afr. J. Agric. Sci. 5(2), 315-329.

CHAMPAGNOL, F., 1980. La matière organique des sols de vigne du Midi de la France. Progrès Agric. Vitic. 97(8), 161-173.

CONRADIE, W. J., 1981. Nutrient consumption by Chenin blanc grown in sand culture and seasonal changes in the chemical composition of leaf blades and petioles. $S$. Afr. J. Enol. Vitic. 2(1), 15-18.

SAAYMAN, D., 1973. Grondeienskappe en wingerdprestasie in die Bonnievale-omgewing. M.Sc.-tesis, Univ. Stellenbosch, Stellenbosch, 7600 .

SAAYMAN, D., 1974. Bemesting van wyndruiwe en druiwe vir drogingsdoeleindes volgens grondsoort en opbrengs. Wynboer, 516, 34-35.

ZEEMAN, A. S., 1981. Oplei. In: Wingerdbou in Suid-Afrika, 185-201. Reds. J. D. Burger \& J. Deist. Trio Rand/S.A. Litho, N'dabeni. 